\title{
Watching Big Brother UK
}

\author{
Annette Hill1 \\ Universidade de Westminster
}

\begin{abstract}
Resumo: Este artigo trata da relação entre a audiência e o reality show Big Brother, com especial ênfase na maneira como esta se envolve com o comportamento dos participantes do programa. $O$ trabalho em questão tem como base uma pesquisa multimetodológica, com resultados quantitativos $e$ qualitativos, realizada no período de 2000 a 2001 no Reino Unido. A autora apresenta dados mostrando o alto grau de participação da audiência do Big Brother, assim como informações sobre o seu contexto socioeconômico. A pesquisa indica que os aspectos sociais e performativos do programa são centrais para se entender o sucesso desta produção. Os momentos de autenticidade percebidos pela audiência são fundamentais para o envolvimento da mesma nos debates de caráter sociocultural despertados pelo Big Brother.
\end{abstract}

Palavras-chave: Big Brother; Pesquisa de Audiência; Autenticidade; Performance.

\begin{abstract}
This article deals with the relationship between audience and the reality show Big Brother, offering a special focus on the engagement of the former with the way participants on the program behave. This work is based on a multi-methodological research, with quantitative and qualitative results, that took place in the United Kingdom in the years of 2001 and 2002. The author not only introduces a range of data showing a high level of engagement of the Big Brother audience, but also outlines its socioeconomic context. The research shows that the social and performative aspects of the program are vital for an understanding of its success. The moments of authenticity grasped by the audience are fundamental for its engagement with the social-cultural debates raised by Big Brother.
\end{abstract}

Keywords: Big Brother; Audience Research; Authenticity; Performance.

\footnotetext{
${ }^{1}$ Annette Hill é professora de Mídia e Audiência e diretora do Centro de Pesquisa da Escola de Mídia, Artes e Design da Universidade de Westminster, na Inglaterra. É autora de Shocking Entertainment: Viewer Response to Violent Movies (1997), co-autora de TV Living:

Television, Audiences and Everyday Life (com David Gauntlett 1999), como também de uma variedade de artigos sobre audiência e cultura popular. É co-editora (com Robert C Allen) da coletânea Routledge Television Studies Reader (2003) e autora de livro Reality TV: Audiences and Popular Factual Television (Routledge 2004).
} 


\section{Introduction}

In the newspaper article 'The Addicted in Search of the Evicted', fans of Big Brother talked about why they had travelled to London to take part in the Friday night eviction show. One fan explained:

There are certain things that take place every decade and this is one of them, this is a phenomenon and coming here is about seeing a moment of our time in action. When it finishes, this nation is in trouble. Six million people will have to learn how to have conversations again' (Corner, 2000:7).

Another fan commented:

I've changed my routine to fit in with Big Brother (...) when it's over I am going to cry. It'll be like losing a group of friends (...) There's going to be a very big gap in my life' (Corner, 2000:7)

This article is about the experience of watching Big Brother (the UK version of 2000). The way audiences watch and talk about this reality gameshow is significant to our understanding of the success of the series, and also its role in the development of popular factual television. Many people watched Big Brother because their friends and family were talking about it, and many people continued to watch Big Brother in order to have something to talk about with their friends and family. What people talked about is the focus of this article. In particular, I examine the topic of performance in relation to audience discussion of the series. Many viewers are critical of the 'performances' of ordinary people in the Big Brother house, and such criticism leads to debate about the truth claims of this reality gameshow. What follows is discussion by television viewers about the experience of watching and talking about Big Brother. ${ }^{2}$

\section{Research Methods}

Before discussing television audiences and Big Brother in the UK, I want to provide a brief note on the research methods used in this article. The audience data I refer to are taken from an audience research project on television audiences and factual entertainment. The project was funded by The Economic and Social Research

\footnotetext{
${ }^{2}$ Parts of this article have been adapted from the book Reality TV: Television Audiences and Popular Factual Entertainment (Hill, 2004), and the article 'Big Brother: the Real Audience' (Hill, 2002).
} 
Council (ESRC), the Independent Television Commission (ITC) and Channel 4. The project used a multi-method approach, combining quantitative and qualitative techniques to gather data and subsequent analysis of television audiences and popular factual programming in the UK. The main methods used were a quantitative survey, semi-structured focus groups and in depth interviews, and the data were collected during a particular period in the development of the genre of popular factual television (2000-2001).

The survey contained a series of closed questions relating to audience preferences for form, content, sub genres, and use of multimedia, and audience attitudes towards issues of privacy, information, and entertainment in popular factual programming. The survey was a self-completion questionnaire, and was distributed by the Broadcasters Audience Research Board (BARB) to a representative sample of 8216 adults (aged 16-65+) and 937 children (aged 4-15) during August 2000. The data collected allowed me to develop a source of information on the general public and their preferences for and attitudes to a range of factual entertainment in the UK. I analysed the data from a number of perspectives, looking at programme types and content, and audience attitudes, and comparing this data with key demographic information relating to age, gender, class, education, households with/without children, and ethnicity. ${ }^{3}$

The next stage of the audience research involved semi-structured focus groups, where the results of the survey were used to design focus group interviews with children (aged 11-14), young adults (aged 15-18) and adults (aged 18-44), who defined themselves as regular viewers of popular factual television, and were in the $\mathrm{C} 1 \mathrm{C} 2 \mathrm{DE}$ social category, that is lower middle class and working class social groups. The recruitment of participants involved the use of a professional qualitative recruitment agency, and quota sampling in a variety of suburban locations. I selected these participants because the results of the survey indicated that regular viewers of popular factual television were primarily in the above categories. The primary aim of these focus groups was to explore audience attraction to different types of popular factual programming, and to understand what strategies they used to watch hybrid

\footnotetext{
3 With regard to ethnicity, the sample of ethnic respondents is too small in the BARB sample to allow for any useful analysis.
} 
formats within the genre. The focus groups contained a series of open questions relating to viewer responses to sub genres within factual entertainment, the use of non-professional actors, and issues relating to information and entertainment in hybrid formats. Twelve focus groups were conducted in London, each group containing 7-8 participants, and were divided according to age, gender, and access to terrestrial, or satellite/cable/digital television. I selected these groups because the data from the survey indicated that age and gender were key variables relating to audience attraction to factual entertainment, and it was necessary to consider a range of programming available across television platforms. Following an initial coding of the transcripts, I conducted a more discursive analysis that considered group dynamics as well as substantive judgements.

The final stage of the audience research involved in depth interviews with ten families, with children of varying ages, over a six month period (recruited from the focus groups). Four visits were made to the family homes during January to July 2001. Combinations of methods were used - open discussions, observation of families, and participation in watching programmes - in order to understand the social context to watching factual entertainment. In addition, key issues that arose from the focus groups were explored further during the family visits. In my selection of interview subjects, the types of questions asked during the visits, and the timing of the visits, I was guided by a desire to follow new developments within the genre, and to further understand how family viewers responded to these developments in the home environment. Interviews were logged, and partially transcribed, and field notes written up during and after the period of data collection. The in depth interviews provided a wealth of rich data and thick description, and allowed further flexibility for the project to assess the popularity of, and responses to, new hybrid formats and more familiar formats within factual entertainment.

\section{Watching and Talking about Big Brother}

Who's watching Big Brother? Channel 4 had the best Friday night ratings in its history, with 9 million viewers (46 per cent share) tuning in to watch the first series finale of Big Brother. 67 per cent of the UK population watched Big Brother at least once. Over seven million viewers telephoned Channel 4's hotline to vote for the 
winner, which broke the record for viewer participation in a UK TV programme. As for the website, it received three million page impressions each day, which made it Europe's top website during the summer of 2000. The second series averaged more than four million viewers, giving Channel 4 more than a 70 per cent increase on their average broadcast share. Channel 4's digital youth channel, E4, screened Big Brother 2 continuously during the second series, and at peak moments in the house (e.g. Paul and Helen's candlelit tryst) attracted record figures, propelling the digital channel ahead of terrestrial minority channels. ${ }^{4}$ More than 15 million viewers voted to evict contestants, either using interactive TV handsets, or phonelines. The website received a total of 159 million page impressions and 16.4 million video streams were requested. 5 The third series of Big Brother averaged four million viewers, with the live final attracting ten million in the summer of 2002. The fourth series of Big Brother under performed from the previous year, but was still fifth place in the top ten programmes for viewers aged $16-25 \cdot{ }^{6}$ Table One illustrates the ratings for all series of Big Brother at the time of writing.

Table 1: Ratings for Big Brother

\begin{tabular}{|c|c|c|c|}
\hline Series (Channel 4) & $\begin{array}{l}\text { Average } \\
\text { (weekdays) }\end{array}$ & First Show & Final Show \\
\hline $\mathrm{BB} 1$ & $4.6 \mathrm{~m}(25 \%)$ & $3.3 \mathrm{~m}(17 \%)$ & $9 \mathrm{~m}(46.5 \%)$ \\
\hline $\mathrm{BB} 2$ & $4.5 \mathrm{~m}(25 \%)$ & $3.3 \mathrm{~m}(16.5 \%)$ & $7.5 \mathrm{~m}(46 \%)$ \\
\hline $\mathrm{BB} 3$ & $5.9 \mathrm{~m}(28 \%)$ & $5.9 \mathrm{~m}(25.9 \%)$ & $10 \mathrm{~m}(50.6 \%)$ \\
\hline $\mathrm{BB} 4$ & $4.9(24 \%)$ & $6.9(29.3 \%)$ & $6.6 \mathrm{~m}(34 \%)$ \\
\hline
\end{tabular}

Source: Broadcast 1 August 2003

In terms of the survey I conducted, Table Two profiles viewers of Big Brother. Out of the total sample of respondents (unweighted sample 8216), aged 16$65^{+}$, only 30 per cent of the sample had watched the programme. Of that 30 per cent,

\footnotetext{
4 The BARB ratings for Wednesday July 11, 2001 show that 626,000 viewers tuned in to watch E4, compared to 300,000 viewers for Channel 5 and 400,000 viewers for Channel 4 at the same time, 11pm.

5 See Broadcast 31 July 2001.

${ }^{6}$ See Broadcast 1 August 2003.
} 
28 per cent of men and 34 per cent of women watched Big Brother. 16-34 year olds were two times more likely to have watched it than older viewers. 51 per cent of viewers with college education saw the series, compared with an average of 33 per cent of those without. Adults were twice as likely to have seen Big Brother if they lived in households with children. Viewers in the higher social grades were slightly more likely to watch the series than those in the lower social grades. And, viewers with internet access were slightly more likely to watch Big Brother than those without. The profile overall suggests Big Brother attracted upwardly mobile, educated, young adults, the target audience for Channel Four.

Table 2: Big Brother

\begin{tabular}{|l|l|}
\hline Viewer Profile & $\begin{array}{l}\text { Watching Big Brother } \\
\text { (30\% of adults) }\end{array}$ \\
\hline Males & $28 \%$ \\
\hline Females & $34 \%$ \\
\hline $16-24$ & $58 \%$ \\
\hline $25-34$ & $50 \%$ \\
\hline $35-44$ & $36 \%$ \\
\hline $45-54$ & $25 \%$ \\
\hline $55-64$ & $15 \%$ \\
\hline $65+$ & $9 \%$ \\
\hline AB & $35 \%$ \\
\hline C1 & $34 \%$ \\
\hline C2 & $30 \%$ \\
\hline DE & $27 \%$ \\
\hline $15+$ education & $15 \%$ \\
\hline $16+$ education & $33 \%$ \\
\hline $17-18$ education & $38 \%$ \\
\hline $19+$ education & $33 \%$ \\
\hline
\end{tabular}




\begin{tabular}{|l|l|}
\hline Students & $51 \%$ \\
\hline With children & $41 \%$ \\
\hline Without children & $22 \%$ \\
\hline With internet access & $40 \%$ \\
\hline $\begin{array}{l}\text { Without internet } \\
\text { access }\end{array}$ & $33 \%$ \\
\hline
\end{tabular}

In relation to the television series itself, Table Three outlines the favourite Big Brother experiences for viewers. Respondents were presented with a list of experiences (eg visiting the website). The Big Brother experience enjoyed by the greatest percentage of all respondents was watching the live 'eviction' show (59 per cent), followed by seeing ex-contestants talk about their experiences (58\%), watching the nightly TV programme (55 per cent) and talking about the programme with friends/family ( 51 per cent). Those aspects of the Big Brother experience that were most 'interactive', choosing winners and losers, were not as popular with viewers (52 per cent and 48 per cent), although this may have altered with subsequent versions of Big Brother which utilised interactive voting via the Channel 4 digital youth channel E4. Similarly, those aspects of Big Brother associated with the website were also not popular with viewers.7 This was partly because during the first series of Big Brother the website was difficult to download to home computers. Again, this reluctance to visit the Big Brother website, even if viewers had access to the internet, may have altered during subsequent series, with technical improvements and greater access to broadband in the home. Another reason why viewers were not especially interested in the website was because they wanted to watch the television show in order to join in conversations about Big Brother with family and friends. Media coverage of Big Brother also rated poorly with viewers (31 per cent). Clearly, media coverage helped to make the series a 'media event' but also saturated the market with gossip. Viewers

7 Out of main sample, the majority of adults ( $83 \%$ of men and $85 \%$ of women) and children ( $74 \%$ of $10-15 \mathrm{~s})$ had not accessed websites related to factual entertainment. The principle reason sited (by $57 \%$ of adults and $40 \%$ of children) was not having access to the internet. A further $36 \%$ of adults and $25 \%$ of children said that they had not visited the sites because they are not interested in them. Despite the fact that $50 \%$ of 16-24 year olds have access to the internet, $82 \%$ did not access these websites. 
preferred to be part of the media event through first hand experience (watching and talking about Big Brother) rather than reading about it second hand.

Table 3: Big Brother Experiences

\begin{tabular}{|l|l|}
\hline Big Brother Experiences & $\begin{array}{l}\text { Like - } \\
\text { (3o per cent of } \\
\text { adult sample) }\end{array}$ \\
\hline Watching the live 'eviction' programme & $59 \%$ \\
\hline Seeing ex-contestants talk about their experience & $58 \%$ \\
\hline Watching the nightly TV programme & $55 \%$ \\
\hline Choosing the winner & $52 \%$ \\
\hline Talking about the programme with friends/family & $51 \%$ \\
\hline Choosing the losers & $48 \%$ \\
\hline Suggesting tasks & $46 \%$ \\
\hline Media coverage of the programme & $31 \%$ \\
\hline Visiting the 24hour internet site & $15 \%$ \\
\hline Talking about the programme in chat rooms & $14 \%$ \\
\hline
\end{tabular}

The above statistics indicate that the experience of watching Big Brother is social, and involves watching and talking about the show before, during and afterwards. Paddy Scannell maintains that talk is not a minor part of the Big Brother experience, but arguably one of the most important features of the series:

Everyone knows that for a time in the summer of 2000 the only thing that anyone talked about was Big Brother. The amount of comment, discussion, and evaluation that it elicited at the time, in the press, in pubs and buses and households up and down the land was enormous. This talk was not accidental but a structural feature of the show's relational totality of involvements. Involvement showed in talk so that to consider what it was that elicited such a 'discursive ferment' is to get at the heart of the programme's care structure as an event invented for television. The programme invited, indeed, demanded that not only should it be watched on a daily basis but that it should be talked about (Scannell, 2002: 2778). 
How did viewers talk about Big Brother? Perhaps one of the most obvious ways in which audiences engaged with the media event of Big Brother was to declare their involvement or lack of involvement with this reality gameshow. The type of common remarks made about the series illustrate an intense love/hate relationship with Big Brother:

I absolutely hated Big Brother (...) I can't see the attraction to it, I don't find anything appealing about watching it (20 year old mother).

It was so crap. I can't believe people watched that and I've watched it a couple of times cos my boy watched it, because it started appearing in the papers, on the radio, on the news even it was on (39 year old groundsman).

I was totally and utterly obsessed with Big Brother - I sort of planned my life round when it was on and everything and the whole family loved it. (31 year old housewife)

I was addicted to Big Brother. I sort of picked it up about half way through though, once I started hearing all this talk and I had to watch it and see what it was all about, but I did follow it all the time then (36 year old housewife).

Words like 'hated' and 'addicted' indicate the way these viewers situated themselves in the media event of Big Brother. As Scannell points out, public talk about Big Brother is not accidental, and the orchestrated media hype surrounding the weekly nominations and evictions created a rich space for comment and speculation about characters and events in the Big Brother house. The 'discursive ferment' Scannell describes as characteristic of Big Brother talk ensures audiences are aware of the series, even if they do not watch it. The above viewer illustrates how 'hearing all this talk' about Big Brother encouraged her to 'see what it was all about'. Whereas for others, public speculation about the series proved a turn off: 'all you could see on the telly, in the paper Big Brother, Big Brother - it does your brains in' (41 year old carpenter).

There is a common narrative to becoming a viewer of the first series of Big Brother. Many viewers began watching Big Brother out of curiosity, or because a friend encouraged them to watch the series, or because a family member watched the series - not because they wanted to watch the series themselves. As this viewer explained: 
I remember seeing it (...) I turned it on and I was like 'What is this?' I turned it over. And then a couple of weeks later when there was nothing to watch I watched it (16 year old schoolgirl).

This gradual involvement in the series is one common to many viewers. For others, their involvement is more rapid:

I didn't like it at first, I came back (...) it started when I was away, I was away for a month and I came back and like everyone was talking about it. I was like 'What on earth is it?' I didn't know what the big thing was, I put it on and I was like 'this is a joke, this is pathetic!' And then my brother kept having it on, I kept watching and I got so into it. I was addicted! I was like mad, I was like 'I love it, I love it, I love it!' So I ended up absolutely loving it and then it was like it stopped and I was crying. I was crying at the end! [laughs] I got so into it I started crying (17 year old female student).

This viewer came to Big Brother part way through the series. Because she was out of the country, she did not witness the gradual build up of public interest in the series, and therefore entered the Big Brother debate when it was in full swing 'what on earth is this?' Her initial reaction was negative, but as she was regularly exposed to the series her criticism of Big Brother turned into an intense attachment for the series - 'I love it, I love it, I love it!' Her emotional response to the finale is a testament to the strong impression Big Brother made on her life that summer.

Talk about Big Brother encouraged people to watch the series, and to become involved in the day to day lives of the housemates. As people became involved in the micro-politics of the Big Brother house, they talked about the series with other viewers. For Scannell, this type of snowballing was crucial to the way Big Brother became a media event:

Talk was necessary to formulate your own views about who should go, and for that decision to have some validity claims, it needed to be grounded in assessments of the performances of the inmates in the house. Such assessments had a cumulative weight. The more you watched the programme, the more you knew about all the inmates, their personal traits, and the ways they interacted with each other (Scannell, 2002: 278).

For audiences, Big Brother was something to talk about with family, friends, work colleagues, and strangers:

All of my friends have been watching it. Everyone talks about it, don't they? On Saturday we went for a meal, it was a friend of mine's birthday, and we sat round the table and I suddenly went 'Can you 
just tell me has anyone been watching Big Brother?', and they went 'yeh', and then all hell let loose. 'Oh my God he's an idiot' and all that. And that was a table of twenty-five people talking about it. It was the talk of the evening (33 year old female care attendant).

In this example, Big Brother acts as social glue, bringing together a group of people who share common knowledge of the series, making it the talk of the evening'. Scannell's comment on the way in which talk is 'grounded in assessments of the performances' of ordinary people is significant as talk about Big Brother is often about how the housemates perform themselves. As the above example illustrates, it is the activities of the housemates that provide material for gossip and speculation. When a particular dramatic episode occurs many viewers want to talk about what they have seen with others - 'Oh my God he's an idiot'. This specific type of talk about the improvised performances of non-professional actors raises significant issues regarding how audiences assess a hybrid genre such as a reality gameshow. In the next section I examine how watching and talking about Big Brother can lead to healthy debate about the development of popular factual television.

\section{Acting Up}

A reality series like Big Brother can be understood in terms of the tensions and contradictions between the performance of non-professional actors, and their authentic behaviour in the Big Brother house. This is, of course, not the only way to understand Big Brother, and other researchers have commented on the significance of surveillance (Palmer 2002), or the concept of media events (Scannell 2002, Couldry 2002), to our understanding of the popularity and impact of reality gameshows. But, in terms of television audiences, there is evidence to suggest the improvised performances of ordinary people frame discussion of this series, and indeed other reality gameshows.

In an article on Big Brother titled 'Performing the Real', John Corner comments on the 'degree of self-consciousness' and 'display' by the various personalities in the 'predefined stage' of the Big Brother house (Corner, 2002b: 2634). As Corner notes, the performance of contestants gives television audiences the opportunity for 'thick judgemental and speculative discourse around participants' motives, actions and likely future behaviour' (Corner, 2002a: 264). In this section I 
want to focus on the way audiences speculate and judge moments when the performance of non-professional actors breaks down, and they are true to themselves'. Corner sums up this viewing process as follows:

One might use the term 'selving' to describe the central process whereby 'true selves' are seen to emerge (and develop) from underneath and, indeed, through, the 'performed selves' projected for us, as a consequence of the applied pressures of objective circumstance and group dynamics. A certain amount of the humdrum and the routine may be a necessary element in giving this selving process, this unwitting disclosure of personal core, a measure of plausibility, aligning it with the mundane rhythms and naturalistic portrayals of docusoap, soap opera itself, and at times, the registers of game-show participation (Corner, 2002b: 263-4).

Other researchers have also discussed this notion of 'performed selves' and 'true selves' co-existing in hybrid formats within reality programmes. Roscoe and Hight discuss the 'performed' nature of docusoaps, and how this type of construction of documentary footage can open up space for debate about the documentary genre (Roscoe and Hight, 2002: 38). Jane Roscoe comments on how Big Brother is 'constructed around performance', with participants involved in different levels of performance, based on the roles of 'housemate', 'gameshow contestant', and 'television personality', and how audiences are invited to join in with these performances 'across the formats of the different shows' (Roscoe, 2001: 482). Lothar Mikos et al, in their research of Big Brother in Germany, also suggest audiences are engaged in an assessment of performance and authenticity (Mikos et al, 2000).

In my research, audiences frequently discuss the difference between performed selves and true selves in a hybrid format such as Big Brother. In the survey I conducted, 70 per cent of the adult sample believed ordinary people act up in reality programmes (see Hill 2002). This high degree of expectation about the performance of ordinary people in reality programmes means audiences spend a great deal of time speculating and assessing the behaviour of people, and comparing the motives and actions of people who choose to take part in a reality programme such as Big Brother. And they discuss the behaviour of ordinary people in Big Brother on an everyday basis. Here is a typical example of the way viewers talk about acting in Big Brother:

Sometimes, I think, can you really act like your true self when there's a camera there? You know. Maybe in Big Brother a little bit 
more you can act yourself because you're going to forget after a while aren't you? But I'm a bit dubious about people acting themselves... The way they were all acting, the way of their body movements and all that, it just looked too fake (...) to me (21 year old male dairy worker).

This viewer's tentative question about being able to 'act like your true self' in front of a television camera opens the door to speculation about levels of acting in the Big Brother house, and individual contestants' 'true' or 'fake' behaviour.

There is a common mode of engagement when watching Big Brother and this is characterised by discussion that goes backwards and forwards between trust and suspicion of the behaviour of ordinary people in the house. In the following debate, a group of male and female adult viewers discuss the various 'selves' on display in the Big Brother house:

Rick: With Big Brother you don't know if they're playing up, yeah, it's just, it's a weird scenario for them to be in, you must just think (...) well, you don't know what's going on inside their head.

Paul: Maybe you put yourself in that situation and, see, it's like I watch it and if, if I was on Big Brother, I'd want everyone to like me or (...) I think of myself as an alright person but then if I was on there I'd, I'd be acting different, thinking 'I've got to do this cos people are going to like me', so maybe that's, that's why, maybe, I think they're acting up.

Peter: They must have thought about everything they've done and said before they actually said or done it. Not like real life, just someone coming out with a comment, but, this could get me out this week - I better not say that, I better just say 'does anyone want a cup of tea?' Not cos I want to make it but I better ask them to look good.

Pauline: Cos at the end of the day, it's a competition, isn't it? There was seventy grand on the line, wasn't there? I'd act up for it! [laughs]

Their discussion is characterised by a hesitant assessment of the abilities of Big Brother contestants to 'act up'. A point to remember is that the Big Brother contestants are strangers to themselves, and to viewers. Unlike celebrity reality gameshows, such as Celebrity Big Brother, where we know the 'personality' of the contestants beforehand, in the case of ordinary people shows, the participants are strangers to us. Thus, when audiences attempt to judge the difference between the contestant's performing selves and true selves in Big Brother, they cannot refer to past performances but must rely on their own judgement of the contestants' 
behaviour and 'what's going on inside their head'. Inevitably, viewers turn to their own experience, and speculate about how they might behave in a similar situation. The discussion therefore becomes one based on hypothetical situations - 'if I was on Big Brother' - interspersed with knowledge of the format, and the effect of the game on contestant's behaviour - 'they must have thought about everything they've done and said before they actually said or done it.'

Audience assessment of the performance of non-professional actors in Big Brother is often based on how well the contestants play the game, and also how well contestants remain true to themselves. In the above discussion, viewers made an oblique reference to the winner of the first series of Big Brother (Craig), who managed to remain popular with his fellow contestants and viewers by carefully balancing his performing self with his true self. The fact that Craig did regularly ask 'does anyone want a cup of tea?' made him appear like an ordinary person and at the same time someone who was trying to win over fellow contestants. Karen Lury suggests television audiences may be anxious about watching ordinary people perform because "if real people convincingly "put on an act" where can sincerity, authenticity and real emotion be located with any conviction?' (Lury, 1998: 126). In the case of reality gameshows, any 'claims to the real' are immediately undermined by the ability of contestants to 'put on an act'. As Lury explains:

While acting may be pleasurable when we know we are watching a performance (it is after all a "skillful" activity) when an ordinary performer acts, we may become uncomfortably aware of how appearance and reality (the behaviour and the feelings) of the performer may be no more matched in the everyday than they are on screen' (Lury, 1998: 126).

Big Brother has capitalised on this tension between appearance and reality by ensuring viewers have to judge for themselves which of the contestants are true to themselves. In fact, audiences enjoy debating the appearance and reality of ordinary people in Big Brother. There is much potential for gossip, opinion and conjecture when watching Big Brother because this hybrid format openly invites viewers to decide not just who wins or loses, but who is true or false in the documentary/game environment.

Lury also suggests audiences may be uncomfortable about watching ordinary people on television because they have been 'coerced into making a fool of 
themselves, and that their presence or image on screen has been manipulated by technicians, producers and bullying presenters' (Lury, 1998: 126). This type of 'uncomfortable' viewing position is applicable to certain forms of reality programming, such as crime based reality programmes, where people may be perceived as 'victims' of ratings driven popular factual television. However, with regard to Big Brother, the majority of audiences are not so much uncomfortable with the manipulation of contestants, but sceptical that anything that goes on in the Big Brother house can be 'unscripted' and natural. Thus, when contestants are given alcohol as a reward for completing various 'challenges', viewers are unlikely to blame the producers for the drunken behaviour of contestants, but to critically judge the housemates for making fools of themselves. Most viewers think any humiliation, or emotional trauma experienced by housemates is generated by housemates, and therefore cannot be trusted as genuine emotional experiences, experiences that in other circumstances would be viewed more sympathetically.

Most of the people involved in the making of Big Brother argue that ordinary people cannot act up twenty four hours a day. For example, Dermot O'Leary, the presenter of Big Brother's Little Brother, which accompanies Big Brother on Channel 4 and E4 in the UK, claims 'no one can act for 24 hours a day, or indeed, for 24 minutes an hour, so we know that the housemates' reactions are genuine.'(O'Leary, 2003:10). It is not my intention to question the insider's perception of levels of acting in reality gameshows. It is my intention to question how audiences make sense of such truth claims from the makers of Big Brother because the behaviour of ordinary people in Big Brother allows audiences to assess the truth claims of the programme itself. In the following extract, a group of teenage girls discuss an infamous scene in Big Brother (2000). In the scene, 'Nasty Nick' was accused of attempting to influence the voting behaviour of other contestants, and after denying the charge, he retreated to the bedroom, where he packed his suitcase, shed a few tears, and listened to advice from fellow housemate Mel. The girls begin their discussion with a prompt from me about the possible 'crocodile' tears of 'Nasty Nick':

Interviewer: Do you think in that scene when he was crying that was really coming from him? 
Sharon: Erm, it could have been, cos in a way he was kicked out and he didn't have any way of winning now and (...) as you saw, the public was really negative towards him (...)

Nicola: I don't think that's as real life as it could have been, cos they know they're going to make quite a bit of money (...)

Angela: [shakes her head] Big Brother. I felt I knew the people in there, cos after a while, although there's cameras there, in the beginning they all did act up but you can't do it all the time. You know when you're upset and crying you can't act happy, you know what I mean. And you get really close to the people, cos you like get to know them. It's really weird, cos like we're talking about them now as if we know them and it's people we've never ever met in our lives who are on TV.

Interviewer: Are there moments when you're not sure? How do you tell if someone's acting up or not?

Nicola: I think if they're just like acting out of the normal, how you wouldn't expect someone to act and you just think they're acting up whether they are or not.

Interviewer: So, it's sort of based on what you think?

Nicola: Yeah, what you think they should act like, but if they're not acting like that.

Laura: No, but some people are extroverts though, you can't say that. Some people are very forward and open-minded and they don't care what people think. But I think you can always tell when people are showing off.

Angela: Yeah, but if you genuinely like them. Say, I liked Anna and if someone said 'oh, Anna's this, oh Anna's that', I wouldn't think she's acting up, do you know what I mean. I think it depends on your attitude towards the person. Do you know what I mean? Cos people genuinely didn't like Nick cos they'd seen that he was doing these kinds of things (...) yeah and I hated Mel so whatever anybody said that was good about her, I was like 'oh, I don't like her, whatever she does, she's a bitch.'

Sharon: I think the only people that could tell if these people are acting up are the people that knew them. We don't know them so we couldn't really judge.

Interviewer: Do you end up judging anyway?

Sharon: Yeah, well I do!

Laura: But they have to be acting up at the end of the day cos if they want to get our votes, they can't sit there and (...) say, they're a really bitchy person, they're not going to sit there and literally be a bitch 
about everyone cos then they're going to be kicked out. They've got to put on an act, they've got to try and make the effort and they've got to try and sweeten us up so we wont kick them out.

Angela: But none of them know, that's the thing, none of them in the house would actually really know if like one of them was acting up or not (...)

Laura: That's what I'm saying.

There are several points raised in this discussion that are relevant to the issue of performance. The first is that there is no clear agreement about the performing self and true self of the character of Nasty Nick. Even though he appeared to break down and reveal his true self in a moment of personal conflict, according to these viewers he needed sympathy from the public, and therefore his tears could be perceived as part of a performance. They are suspicious of Nick because they have witnessed his duplicitous behaviour prior to the housemate's intervention, and because he is a contestant in a gameshow. Another point is that the discussion has a backwards and forwards rhythm characteristic to talk about what is real and what is not in reality gameshows. Big Brother is not 'as real life as it could have been' because of the gameshow element to the format, but contestants in the house can't act all of the time, so parts of it are real. We 'get to know' the housemates intimately, as if they are people we have actually met in our everyday lives, but 'we don't know them' because we have never really met them. In many ways their discussion about acting highlights a philosophical conundrum - how can we really know what we are seeing is real?

The sociologist Erving Goffman, in his book The Presentation of the Self in Everyday Life claims we are all performing all of the time. We perform our 'selves' on various different stages, such as work or home, to various different audiences, such as our boss, or our family. For Goffman, our houses, cars, clothing, and other such everyday items are 'props' and 'scenery' required for the 'work of successfully staging a character' (Goffman, 1969: 203). In any social encounter, a performer will be aware of their audience and vice versa. The process of communication between the performer and audience is an 'information game', where performers will reveal and conceal their behaviour to others (Goffman, 1969: 20). On the Big Brother stage there are two types of audience, one that is inside, and another that is outside the 
house. The inside audience has first hand knowledge of the performance of individuals within the group, but this knowledge is only partial, as the contestants cannot witness all the actions, or performances, of the other members of the social group. The outside audience has second hand knowledge, but is witness to, in Goffman's terms, the 'front' and 'backstage' behaviour of the housemates via the twenty-four hour surveillance cameras. By front and backstage, Goffman refers to moments in social interaction when an individual ceases to play a part convincingly, when we see beyond a 'personal front', to the real person inside the performer (Goffman, 1969: 34). In the discussion by the teenage girls about the performance of housemates they highlighted how 'none of them in the house would actually really know if like one of them was acting up or not'. This would suggest that viewers of Big Brother would have a privileged position in the 'information game', and be able to anticipate future incidents or behaviour, based on prior knowledge of the front and backstage behaviour of housemates. Certainly, in the scene with Nasty Nick, confrontation by the other housemates disrupted the natural harmony of the Big Brother house, literally 'creating a scene' which millions of viewers tuned in to watch. The housemates intervention provided a backstage view of one particular performer, and cast a shadow on the believability of his remaining performance in the house. Audiences were already suspicious of Nick's performance prior to the intervention, and remained suspicious at the point when he had lost everything, and was most likely to reveal his 'true self'.

Although the above discussion suggests viewers do feel they have a bird's eye view of events in the Big Brother house, there is a general questioning of how viewers can really get to know these performers at all. According to Goffman, when social interaction occurs, there is a 'natural movement back and forth between cynicism and sincerity' on behalf of performers and audiences(Goffman, 1969: 31). In the teenage girls discussion of Big Brother there is a 'natural movement back and forth' in their talk of how viewers judge the sincerity of ordinary people in reality gameshows. It is in the act of trying to judge the scene change from performing self to true self that audiences debate whether what they are watching is true or not. And, it is in the act of talking about the truth claims of Big Brother that audiences debate significant issues concerning the authenticity of popular factual television. The more audiences watch 
and talk about reality TV, the more knowledge they have about how reality TV is put together (see Hill 2004 for further discussion). As these two teenage girls explain:

Laura: The next Big Brother will be rubbish (...) They'll be trying too hard, everyone knows what to expect now and they're all going to try so hard! They'll know now what to do and how they can win people's votes $(\ldots)$

Angela: Yeah, but then again, we'll have just as much knowledge as they do.

\section{Conclusion}

When audiences watch Big Brother they are not only watching it for entertainment, but they are also engaged in critical viewing of the attitudes and behaviour of ordinary people, and the ideas and practices of the producers of Big Brother. As John Ellis points out, audiences of reality programming are involved in exactly the type of debates about cultural and social values that critics note are missing from the programmes themselves: 'on the radio, in the press, in everyday conversation, people argue the toss over "are these people typical?" and "are these really our values?”' (Ellis, 2003: 11).

The sites we associate with reality series such as Big Brother are stages where ordinary people display their personalities to fellow performers and to audiences. The fact that Big Brother is set up to encourage a variety of performances, as contestants, as TV personalities, ensures such programmes are viewed as 'performative' factual entertainment. The manner in which ordinary people perform in Big Brother is subject to intense scrutiny by audiences. Audiences gossip, speculate and judge how ordinary people perform themselves and stay true to themselves in the spectacle/performance environment of Big Brother. Audience discussion is characterised by a natural movement backwards and forwards between trust and suspicion of the truthfulness of ordinary people and their behaviour on TV. Whether people are true or not in the way they handle themselves in the Big Brother house is a matter for audiences to debate and critically examine on an everyday basis. When audiences debate the authenticity of performances in reality programming they are also debating the truth claims of such programmes, and this can only be healthy for the development of the genre as a whole. 


\section{Acknowledgements}

I would like to thank the people who took part in the focus group discussions and in depth interviews for their time and their insights into the viewing experience of Big Brother. I would also like to thank Caroline Dover for her expert assistance in this research project.

\section{Bibliography:}

Corner, J. (2002a). 'Documentary Values', in A. Jerslev (ed.) Realism and 'Reality' in Film and Media, Copenhagen: Museum Tusculanum Press, 139-158.

Corner, J. (2002b). 'Performing the Real', Television and New Media, 3 (3), 255-270.

Corner, L. (2000). 'The Addicted in Search of the Evicted', The Independent (29 August), 7.

Couldry, N. (2002). 'Playing for Celebrity: Big Brother as Ritual Event', Television and New Media, 3 (3), 283-294.

Ellis, J. (2003). 'Big Debate is Happening Everywhere but on TV', Broadcast (27 June), 11.

Goffman, E. (1969). The Presentation of Self in Everyday Life, London: Pelican Books (reprint).

Hill, A. (2002). 'Big Brother: the Real Audience', Television and New Media, 3 (3), 323-340.

Hill, A. (2004). Reality TV: Television Audiences and Popular Factual Entertainment, London: Routledge.

Lury, K. (1996). 'Television Performance: Being, Acting and “Corpsing”, New Formations, 27, 114-127.

Mikos, L., Feise, P., Herzog, K., Prommer, E., and Veihl, V.. (2000). Im Auge der Kamera: Das Fernsehereignis Big Brother, Berlin: Vistas.

O’Leary, D. (2003). 'Interview', in Heat, (31 May - 6 June), 10.

Palmer, G. (2002). 'Big Brother: an Experiment in Governance', Television and New Media, 3 (3), 295-310.

Roscoe, J. and C. Hight. (2001). Faking It: Mock-documentary and the Subversion of Factuality, Manchester: Manchester University Press.

Roscoe, J. (2001). 'Big Brother Australia: performing the 'real' twenty-four-seven', International Journal of Cultural Studies, 4 (1), 473-488.

Scannell, P. (2002) 'Big Brother as Television Event', Television and New Media, 3 (3), 271-282. 